\title{
DDS Perspective: Deborah D. Proctor, MD
}

\author{
Deborah D. Proctor ${ }^{1,2}$
}

Accepted: 13 April 2021 / Published online: 2 July 2021

(C) The Author(s), under exclusive licence to Springer Science+Business Media, LLC, part of Springer Nature 2021

\section{Just Do the Best You Can}

"Just do the best you can." These words would often ring in my ears and bring me back to my first medical missionary trip to El Progreso, Honduras in 2005. That spur-of-themoment trip would change my life. I had agreed to come to Progreso as the physician in charge of 25 medical personnel who would in aggregate, evaluate, and manage over 1,100 patients in five days with two dentists whom I had met through a mutual friend. [1, 2] It was hot - the sun gave new meaning to the word "heavy" — and buggy, and I knew only two words in Spanish. After our group had spent all day setting up our clinic and the realization of what I was going to do over the next week had settled in, I more or less panicked. I went to my dental friend who was the leader of our group and told her that I did not think that I could do what was needed. This was when I heard these words for the first time, "Just do the best you can." When I thought about what they meant, I realized I could do that. I might not do as good of a job as someone else would, but I could do the best that I could do. Over the subsequent 16 years, I have heard many iterations of this phrase: "Just show up"; "All you need is a seat at the table"; "Just do it"; "Lean in"; and others. They all basically mean the same thing: All anyone can ask is to do your best in any given situation.

Fast forward to November 2020. Eight months into our COVID pandemic, I needed to check on the children and staff at our orphanage, Comite Progreseno Para la Proteccion al Menor, or COPPROME. [3] Over the past 16 years, my work in Honduras had morphed from providing onetime general medical care annually to patients in rural areas to founding a non-profit with my family ten years earlier,

Deborah D. Proctor

deborah.proctor@yale.edu

1 Department of Internal Medicine, Yale University School of Medicine, New Haven, USA

2 Section of Digestive Diseases, Yale Inflammatory Bowel Disease Center, 40 Temple Street, Suite 1A, New Haven, CT 06510, USA
Honduras Children's Project (HCP) [4], whose mission is to educate the 40-50 children who call COPPROME their home. Over the years, HCP effectively partnered with several other groups to keep COPPROME operational and not only running successfully, but also improving aspects of the lives of our children. The children regularly pass through each grade, with several attending private, bilingual schools and the teenagers graduating from university, but none of this had previously been happening. I usually make 3-4 trips annually to COPPROME, but because of the travel restrictions imposed by COVID, I had not visited our orphanage, children, and staff since February 2020. I felt "safe" traveling to our orphanage in Honduras because COVID had swept through the orphanage in the summer with everyone who worked or lived at COPPROME surviving, albeit some with lingering symptoms. Additionally, I had been working with COVID patients for the past eight months and utilizing appropriate personal protective equipment and had managed to avoid contracting the disease. I planned on quarantining at the orphanage, which was where I always stayed when I visited anyway.

This all being said, I knew this trip was going to be a different experience. I just had no idea how extraordinary it was going to be. As I landed in San Pedro Sula, Honduras for my 35th visit, I thought back to the first time I had flown over these beautiful palm and banana trees many years ago. Although I knew each time, I came to COPPROME things were unique, this particular trip was already notable for being my "COVID trip." We were eight months into the pandemic, vaccines were on the horizon but not available yet outside of clinical trials, and sections of the U.S. were experiencing rising cases after school openings and other activities. My home state of Connecticut had experienced a first horrible wave of ill patients and deaths in the spring and was beginning to undergo our second wave, which would turn out to be less severe than the first, but still significant.

Traveling had already noticeably changed. To get on the plane, I needed a negative COVID PCR test (check) and permission from the Honduran Ministry of Immigration via an on-line form. I had filled out the immigration form at home 
but apparently failed to save it, so at the Atlanta airport, I needed to refill it out on my iPhone. I thought it was challenging to fill the form out on my computer at home, but it was doubly challenging to do so in a hurry at the airport. I was the last passenger on the plane; the doors closed behind me.

When I landed in San Pedro Sula, no one was in the airport terminal to greet me; they were waiting outside with masks on. I received only virtual hugs from people who I had known for 16 years and had not seen for nine months. Tears quickly filled all of our eyes as it dawned on me what this trip was going to entail.

When I arrived at COPPROME, out of respect for my visit (I was the first international visitor since February 2020), the children were getting tested, and the same ones, who were positive in the summer, were still positive. How was this possible? Fear filled me again as I wondered whether I would really be able to avoid contracting COVID during the week I was planning to stay? My face was already aching from wearing my N95 mask for the past eight hours of traveling, and a new issue was that I was sweating under my mask in the Honduran heat. I quickly decided that it would be a good idea to get the positive cases tested via PCR in town and that I would need to take scheduled breaks during the day if I were to survive the next week. I went into my room at the orphanage, took off my mask, and washed my face; this felt good.

Regrouping after a few minutes, I suggested that we take the "positive" children to get tested at a more reliable center. We did, and all the positive cases now tested negative. I felt my anxiety level fall as I realized that I would be quarantining in a place where everyone was negative, as I had anticipated.

No hugs from the children were going to take place on this trip. However, we soon practiced elbow bumps, and the young kids would sit on my lap with their masks pulled somewhat up over their mouths and noses. They would pull their masks up whenever I came near; I was honored that they thought enough about me to do this. (Fig. 1).

Eating took place outside and away from the children so that I could drop my mask. This was not as much fun as previous visits but safer under the circumstances.

The first few days of my visit passed quickly, and then, we got word that Hurricane Eta was approaching Central America. Computer modeling had San Pedro Sula taking a direct hit after the storm traveled through Nicaragua, which was south of us. As it turned out, Eta took a U-turn through the lowlands and plains of the portion of Honduras where COPPROME is located, spending more than $24 \mathrm{~h}$ over us and dumping about four feet (48 inches) of rain in a $24-\mathrm{h}$ period.

As the rain began, my friends started talking about flooding. I soon found out what this meant. The torrent of rain

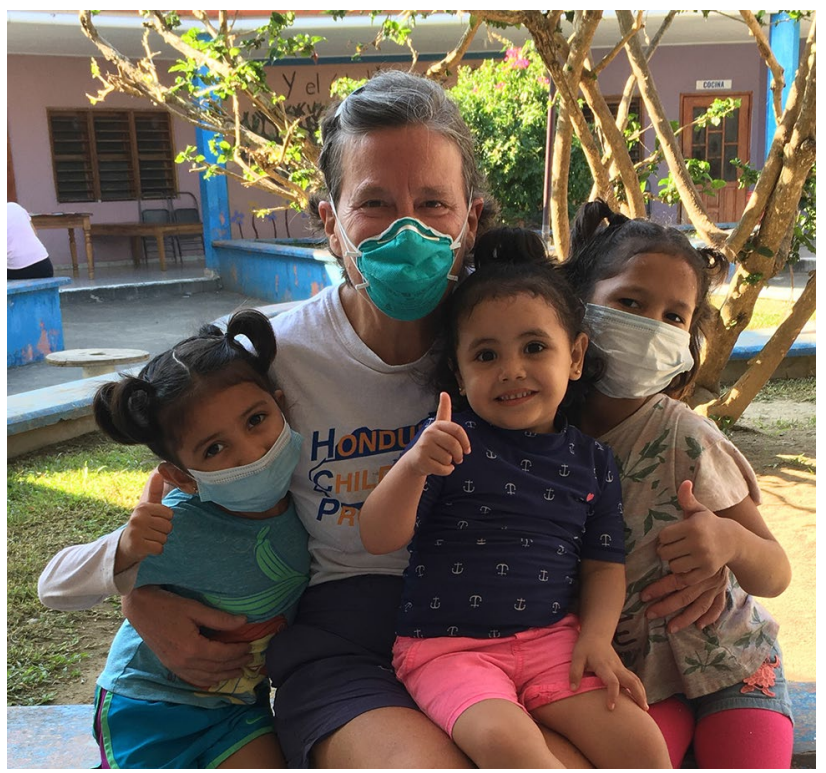

Fig. 1 D Proctor with three of the COPPROME children

continued so loudly for so long (about 1-2 inches each hour) that it was like a shower full force that would not turn off. After about $16 \mathrm{~h}$ of listening to this deafening, nonstop noise, I had a splitting headache. When was the rain going to stop?

The following day, the rain finally ceased, and it was time to assess the damage. Our electricity was out, which also meant we had no water, internet, or cell service. However, we could still cook because the kitchen stove was gas fired. Our buildings, including the roofs, were still standing, and there was standing water around the property, but no flooding. The Ulua River flows about 100 yards away from our buildings. Somehow only the left bank had blown out; we are on the right bank with flooding over ten miles to the east of our buildings but completely sparing COPPROME. As I walked around and saw the massive damage as the river flowed down from the mountains carrying everything trees, houses, animals, people - with it, the extent of the damage started to dawn on me.

As the day progressed, word began trickling in about houses being flooded to the rooftops and people unable to get out of large swaths of houses. Another day went by, and stories continued to come to us at COPPROME. The road we took into town was half washed away, but we could still drive into town. The airport was under 10-12 feet of water, and I was going to have to stay for a few more days than I had originally planned.

On day 2 after Hurricane Eta, my friend asked me to help her make food for the stranded people and those who did not have means to cook. We went to another friend's house and made food for over 200 people. (Fig. 2) 


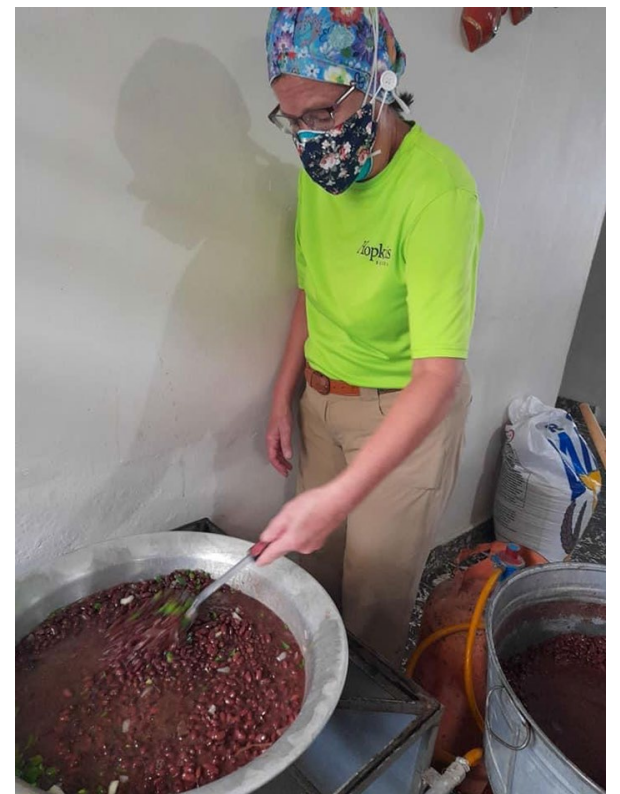

Fig. 2 D Proctor helping to prepare food for 200 people

Afterward, when we started delivering the food, I had a direct view of the devastation from the floods. One of the first things we did was to drive up a mountain road as far as we could go, stopping when we reached a point where the road was washed away. There were a few people who were walking down the road with whom we shared our meals. The amazing thing was the view: miles of plains and fields had been replaced by a lake. I could now see the extent of the flooding, but it was still difficult to grasp.

Our next stop was a shelter in a school yard. School buildings turned out to be ideal shelters for the flood victims; the buildings were not being used due to COVID, and they had separated rooms and bathrooms on site, although electricity and running water would not be available in many places for another week. Crowding by the flood victims was made even more complicated by COVID. It was impossible for people to socially distance. Medical personnel came daily to test the new arrivals for COVID and would quarantine the people who tested positive into separate rooms, but this soon became a losing battle.

The following days we made more food and took more trips to places where people were living and sleeping on high ground. One night stands out in my mind. As we were delivering food to people sheltering by the side of the road, several told us that they had already eaten but that the people farther along the road had not been reached yet. They asked if we could drive a little farther and deliver food to these people. They had lost everything but were willing to share offered food with their fellow flood victims. I was beginning to see - and feel - the good in people shining through.
Three to four days after the hurricane, we went down to the Ulua River and met people who had just been rescued from their rooftops. The expressions on their faces as they set foot on dry land are ones that are difficult to erase. Knowing that they had been clinging to rooftops for several days without water or food in the hot sun and had just been rescued in a small 20-person motorboat and brought upriver is a concept that was difficult for me to grasp. I was not a person who had experienced this type of trauma. I did not sleep that night as visions of these rescued people kept flashing through my mind.

The rescuers are the most amazing people I have ever met. One is a friend who I have known for several years. These boat captains were the true heroes. My friend would make three to four trips down river each day for several days after the hurricane. He would find 15-20 people and somehow (I am not sure how, because if someone fell off a roof, he or she would literally be swept downstream in a current that made white water rafting a challenge) get them into his 20-25 foot motorboat, all the while not being swept downstream himself. Add 100-foot tree trunks, branches, and mud as well as everything else being washed down from the mountains into the river, and I am amazed that his boat was not destroyed, nor his propeller tangled in the debris.

Throughout all of this, the COPPROME children helped make food for the flood victims. The gas stove in our kitchen continued to work despite the lack of electricity and running water. The teenagers in particular were excellent chefs, and the food we all made was much appreciated.

After a few days of cooking food, the COPPROME children decided they wanted to do more. At their own initiative, the teenage girls and boys went through their closets and bundled up their clothes to take to the flood victims. I will remind the reader that these are children who are living at an orphanage because they do not have a family of their own or because their families are too poor to take care of them. The idea that they would give up something that belongs to them to help someone who they believed was less fortunate than they strains the boundaries of understanding. My heart filled with joy at the kindness of spirit these children were showing.

A week after Hurricane Eta, I drove around La Lima, one of the hardest hit communities. (Fig. 3) Many of the flood waters had receded, but the mud, trees, garbage, and debris that remained were hard to wrap my arms around. Huge communities of people were taking all of their belongings out of their houses and piling them on the streets for removal. And did I mention the mud?: 6-12 inches of thick brown mud that turned as hard as concrete when the water evaporated in the hot sun covered everything. It was not clear how, or when, this was going to be removed.

A beacon of hope came in the form of a video that quickly went viral in Honduras. There was a caravan of trucks 


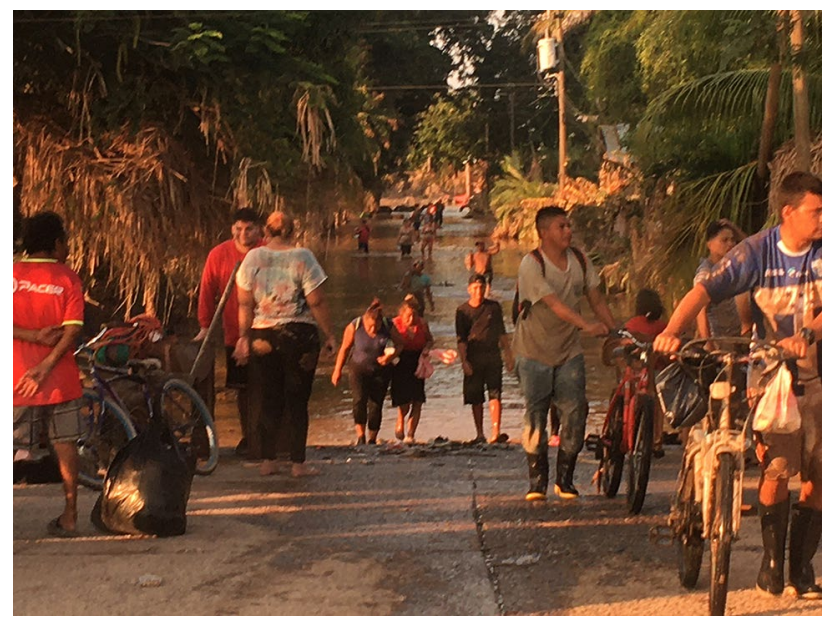

Fig. 3 La Lima - Hondurans walking through the still flooded streets one week after Hurricane Eta

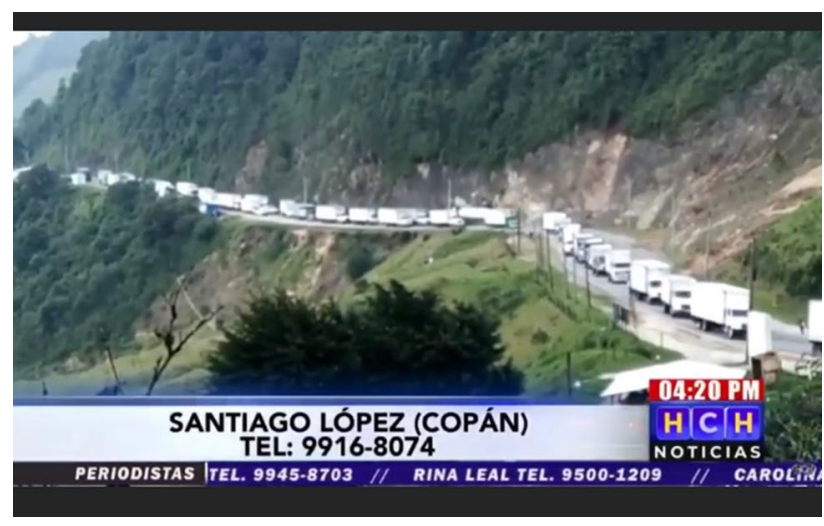

Fig. 4 A caravan of trucks coming over the mountains from El Salvador

crossing the border from neighboring El Salvador filled with supplies for the flood victims! (Fig. 4) What a welcome site this must have been for the people who had lost everything.

The San Pedro Sula airport would remain closed for another two and a half months, as it needed to be cleaned out with everything replaced. One week after I had originally planned to leave, my friends drove me over the mountains to the Tegucigalpa airport to catch a flight back to the U.S.
The road over the mountains opened the day before we drove on it; it had been washed out in a couple of places. As we drove over the mountains, I saw that a large bridge that I had driven over during past trips had been completely washed away. Fortunately, there was another bridge that spanned this particular river.

A week after I left, a second hurricane, Iota, repeated almost exactly what Eta had done to the plains of San Pedro Sula and El Progreso. COPPROME remained standing again.

Yes, the good in people shines most brightly during times of trial and tribulation. Heroism occurs during times where and when it is needed. I have had the privilege of seeing the bravery and heroism of my friends and colleagues in Honduras shine most brightly during my November "COVID trip." Somehow I do not believe this will be the last time I will experience the generous spirit and helping nature of people who I know have little but yet are willing to share with those who have less.

"Just do the best you can." These words will continue to ring true for me but are also demonstrated over and over again by the tremendous spirit of sharing and goodwill exemplified by my friends and colleagues in Honduras.

\section{Declarations}

Conflict of interest The author declares that they have no conflict of interest.

\section{References}

1. Proctor DD. Missionary work - it's about more than doing endoscopies. AGA Perspectives 2013;9:22-23.

2. Proctor DD. How to get involved in global health. Gastroenterology 2019;156:542-544.

3. https://en.wikipedia.org/wiki/Copprome_Orphanage

4. www.honduraschildrensproject.org

Publisher's Note Springer Nature remains neutral with regard to jurisdictional claims in published maps and institutional affiliations. 